\title{
Bjarne Stoklund 1928-2013
}

B jarne Stoklund, prof. i etnologi ved Københavns Universitet 1971-1996, døde 3. maj i en alder af 85 år. Han vil blive savnet på faget, for Bjarne var stadig en værdsat del af fagmiljøet på Etnologi, hvor han nød at have sit kontor, skrive og tage del i debatter. Hans interesse for de aktuelle forhold på universitetet var usvækket, men han så det som pensionist som sin pligt og sit privilegium at holde sig fra at præge debatten med sine egne holdninger. Når gæstende kolleger spurgte til Bjarne, var det altid en bekræftelse på vort fagmiljøs værd at kunne sige, at han fortsat var aktiv og nærværende på instituttet. Nu er han pludseligt blevet afbrudt i sit faglige arbejde.

Siden han tiltrådte professoratet i Materiel Folkekultur i 1971 og omdøbte faget til Europæisk Etnologi har generationer af etnologistuderende draget nytte af hans faglige engagement og store viden. Bjarne var ikke bange for at tage nye ting op, men formåede også at holde fast på kvaliteterne i tidligere forskning og viden. Ikke uden grund kaldte han i 1971 sin tiltrædelsesforelæsning på Europæisk Etnologi for Mellem Scylla og Charybdis og fremstillede sit fag som ét, der måtte finde en reflekteret balance mellem de synkront arbejdende, men helhedsorienterede dele af antropologien og de historiserende, men element-tænkende dele af kulturhistorien. Dette balancerende perspektiv blev han lært op i allerede som studentermedhjælper hos Svend Jespersen på Nationalmuseets 3. afdeling, hvor Bjarne blev en flittig deltager på de årlige optegnelsesrejser i 1950'ernes stort anlagte bondegårdsundersøgelser. Her forvandlede han sig fra den unge studerende til den udlærte forsker, som i 1958 fik ansættelse på Frilandsmuseet. Her fik han mulighed for at dyrke gårdforskningen i nær tilknytning til den museale hjemtagning og genopbygning af huse fra før industrialiseringen. Flere af hans bøger handler om at bruge studiet af disse huse til at fortælle landbokulturens udvikling, og foregreb således nyere forsøg på at integrere mikro- og makroperspektiver i kulturhistorien. Et andet resultat af den etnologiske forskning på Nationalmuseet var uddelegeringen af lokalstudier til de unge medarbejdere, hvor Bjarne kom til at tage sig af Læsø, hvorfra hans fars familie og efternavnet Stoklund stammer. Studiet af Læsø fra middelalder til nutiden i et komplekst samspil mellem lokaliteten og den omgivende verden fulgte ham fra studentertiden, over årene på Frilandsmuseet og som universitetsprofessor, og forblev centralt til det sidste. Han var således ved sin død ved at færdiggøre et bogmanuskript med resultaterne af de mangeårige studier af transformationsprocesserne i Læsøs økologi og kultur fra 1500 til 1900. Bjarne Stoklund brugte også flittigt sit otium til at færdiggøre andre af et langt livs forskellige etnologiske undersøgelser, hvoraf udgivelsen af 
Tingenes Kulturhistorie og studierne af de middelalderlige fiskerier i Danmark, samt Færøhuset er de væsentligste.

Da Bjarne Stoklund tiltrådte som professor var faget i opbrud, og han bidrog sammen med yngre svenske kolleger til en modernisering af faget, der introducerede de studerende til nye retninger og interesser i den skandinaviske etnologi. Det var således ham, der introducerede faget til amerikansk kulturøkologisk tænkning og til semiotiske analyser af dragter og andre kommunikative genstandsformer. Familie og hushold, natur og kultur, økologi og bondetyper og endelig nationsdannelse blev nogle af de temaer, der nu er indskrevet i fagets kanon. Bjarne Stoklund var også den, der gennem sit virke utrætteligt sikrede, at det eneste danske universitetsfag i etnologi var i fortsat og tæt kontakt med fagmiljøerne i Norden og det øvrige Europa. I den forbindelse virkede Bjarne Stoklund fra 1988 - 1996 som dansk medlem af editorial board for Ethnologia Scandinavica og fra 1984 - 2004 som hovedredaktør af Ethnologia Europaea. Både nationalt og internationalt sikrede Bjarne den danske etnologis anerkendelse, bl.a. ved at han i 1991 blev indvalgt i Det Kgl. Danske Videnskabernes Selskab og i 1997 for en periode var gæsteprofessor ved universitetet i Edinburgh. I 1994 inviterede præsidenten for SIEF (Société Internationale d'Ethnologie et de Folklore), professor Konrad Köstlin, Wien, Bjarne Stoklund til at blive medlem af bestyrelsen af SIEF, med henblik på at styrke kontakterne mellem SIEF og Ethnologia Europaea.

Bjarne Stoklunds publikationer er kendetegnet ved en flydende og ubesværet fremstilling med kærlighed og sans for den empiriske mangfoldighed og detaljens betydning. Han gjorde ikke noget stort nummer ud af det teoretiske arbejde, men det ligger i stedet implicit i hans publikationer. Dertil kommer hans stærke fornemmelse for sammenhænge på tværs af både tid, rum og nationale grænser, og dette gav ham samarbejde med forskere fra mange fagtraditioner over hele Europa og i Norden, hvor især det Nordatlantiske område havde hans interesse. Hvor man end rejste med Bjarne Stoklund, havde han venner og kolleger, der tog imod ham (og hans yngre kolleger) med åbne arme. Han vil også blive husket af sine studenter for de fantastiske rejser og ekskursioner i Danmark og Europa, han arrangerede.

Gennem hele sin tid som professor skrev Bjarne Stoklund på sin egen version af faghistorien, der som historieskrivning oftest er, også var egnet til at sætte en politisk dagsorden for, hvordan han gerne så faget udvikle sig. Bjarne var dermed til det sidste engageret $\mathrm{i}$ at fortsætte diskussionen om, hvad der var op og ned i fagets udvikling. Nu er Bjarne Stoklund selv gået over i faghistorien, og dér er vi glade for at kunne beholde ham som et varmt menneske, hvis bidrag og synspunkter det fortsat er værd at debattere med, fordi deres kvaliteter holder langt ud over det menneskeliv, der er så meget kortere end etnologiens. 